\title{
EFFECT OF NITROGEN FERTILIZATION ON THE YIELD AND NUTRITIVE VALUE OF BETA VULGARIS L.
}

\author{
Katarzyna Dzida, Zbigniew Jarosz, Zenia Michałojé \\ Chair of Cultivation and Fertilization of Horticultural Plants \\ University of Life Sciences in Lublin
}

\begin{abstract}
Leaf beet is one of several types of Beta vulgaris L. The vegetable originates from the Mediterranean area but is currently grown on a large scale in the US and Western Europe, e.g. Switzerland, Germany, France or England. In Poland, it is a less known vegetable, despite its high content of many valuable nutrients and excellent taste. One of the main factors affecting the size and quality of yield is nitrogen fertilization. Nitrogen is a structural element of plants and its deficiency significantly inhibits production of new plant tissue. This element is a component of nucleic acids, nucleotides, coenzymes, chlorophyll, phytohormones and cytokinines. The aim of this study was to conduct research on the effect of varied nitrogen fertilization on yielding and chemical composition of aerial parts of leaf beet. The experiment used three doses of nitrogen $\left(0.2,0.4,0.6 \mathrm{~g} \mathrm{~N} \mathrm{dm}^{-3}\right.$ of medium) in the form of ammonium nitrate or urea. Plants were cultivated in a greenhouse, in 4-litre pots filled with highmoor peat limed to $\mathrm{pH}$ of 5.6 with waste chalk. The following fertilizers were used in the experiment: ammonium nitrate $-34 \% \mathrm{~N}$, urea $-46 \%$ $\mathrm{N}$, monobasic potassium phosphate $-23 \% \mathrm{P}, 28.2 \% \mathrm{~K}$, magnesium sulphate $-15.6 \% \mathrm{Mg}$, and microelements. In the cultivation of leaf beet, application of $0.4 \mathrm{~g} \mathrm{~N} \mathrm{dm}{ }^{-3} \mathrm{NH}_{4} \mathrm{NO}_{3}$ proved to be most beneficial as it led to the highest yield of fresh mass of leaves and highest content of L-ascorbic acid, whereas application of $\mathrm{CO}\left(\mathrm{NH}_{2}\right)_{2}$ in the amount of $0.2 \mathrm{~g}$ $\mathrm{N} \mathrm{dm}{ }^{-3}$ of the growth medium proved to be best, as it resulted in the lowest nitrate share in the dry mass of leaves. Regardless of the type of nitrogen fertilization, growth in the total salt concentration (EC) in the medium was shown as an effect of increasing doses of the applied fertilizers. Increasing the nitrogen concentration by $100 \%$ in the growth medium in relation to the lowest dose raised the $\mathrm{Fe}$ and $\mathrm{Cu}$ content in beet leaves and depressed that of $\mathrm{Zn}$ and $\mathrm{Mn}$ irrespective of the applied nitrogen fertilization.
\end{abstract}

Key words: Beta vulgaris L., doses and forms of nitrogen, nitrates, medium, macro-, micronutrients.

Katarzyna Dzida PhD, Chair of Cultivation and Fertilization of Horticultural Plants University of Life Sciences in Lublin, Leszczyńskiego 50, 20-068 Lublin, Poland, e-mail: katarzyna.dzida@up.lublin 


\title{
ODDZIAŁYWANIE NAWOŻENIA AZOTOWEGO NA PLON I WARTOŚĆ ODŻYWCZĄ BURAKA LIŚCIOWEGO
}

\begin{abstract}
Abstrakt
Burak liściowy jest jednym z typów uprawnych gatunku Beta vulgaris L. Ojczyzna buraka liściowego sa kraje leżące w rejonie Morza Śródziemnego. Obecnie roślina ta jest warzywem uprawianym na szeroka skalę w USA, a także Europie Zachodniej: Szwajcarii, Niemczech, Francji, Anglii. W Polsce jest warzywem mało znanym, mimo że zawiera wiele cennych składników odżywczych i smakowych. Jednym z głównych czynników wpływających na wielkość i jakość plonu jest nawożenie azotowe. Azot jest pierwiastkiem budulcowym roślin, a jego niedobór istotnie ogranicza powstawanie nowych tkanek roślinnych. Pierwiastek ten wchodzi w skład kwasów nukleinowych, nukleotydów, koenzymów, chlorofilu, fitohormonów, cytokinin. Celem pracy było określenie wpływu zróżnicowanego nawożenia azotem na plonowanie oraz skład chemiczny części nadziemnych buraka liściowego. W doświadczeniu zastosowano trzy dawki azotu $\left(0,2,0,4,0,6 \mathrm{~g} \mathrm{~N} \mathrm{dm}^{-3}\right.$ podłoża) w postaci saletry amonowej lub mocznika. Rośliny uprawiano w szklarni w doniczkach czterolitrowych wypełnionych torfem wysokim zwapnowanym kreda nawozowa do $\mathrm{pH}$ 5,6. $\mathrm{W}$ doświadczeniu stosowano następujące nawozy: saletrę amonową - $34 \% \mathrm{~N}$, mocznik $46 \% \mathrm{~N}$, fosforan monopotasowy - $23 \% \mathrm{P} ; 28,2 \% \mathrm{~K}$, siarczan magnezu - 15,6\% Mg, mikroelementy. W uprawie buraka liściowego najkorzystniejsze okazało się stosowanie $0,4 \mathrm{~g} \mathrm{~N}$ $\mathrm{dm}^{-3} \mathrm{NH}_{4} \mathrm{NO}_{3}$ ze względu na największy plon świeżej masy liści i największą zawartość kwasu L-askorbinowego, natomiast ze względu na najmniejszy udział azotanów w suchej masie liści najlepsze okazało się podanie $\mathrm{CO}\left(\mathrm{NH}_{2}\right)_{2} \mathrm{w}$ ilości $0,2 \mathrm{~g} \mathrm{~N} \mathrm{dm}{ }^{-3}$ podłoża. Niezależnie od rodzaju nawozu azotowego wykazano wzrost ogólnej koncentracji soli (EC) w podłożu pod wpływem wzrastających dawek stosowanych nawozów. Zwiększenie stężenia azotu o $100 \%$ w podłożu w stosunku do dawki najniższej powodowało wzrost zawartości $\mathrm{Fe}, \mathrm{Cu}$ w liściach buraka, a spadek $\mathrm{Zn}$ i Mn niezależnie od zastosowanego nawozu azotowego.
\end{abstract}

Słowa kluczowe: Beta vulgaris L., dawki i formy azotu, azotany, makro-, mikroelementy.

\section{INTRODUCTION}

Leaf beet (Beta vulgaris L. var. cicla L.), a member of the family Chenopodiaceae, is a biennial plant (KRETSCHMER 1999). In the first year of vegetation, it produces a rosette of oval root leaves, which are sometimes crenulated, with long, slightly ribbed petioles and the colour ranging from silver white through yellow, green, pink to red. The leaf blade can be smooth or bubbly, bending downwards at the edges. Depending on a variety, the color of leaf blades is yellow and green, green or red.

Nitrogen fertilization is one of the main factors affecting the size and quality of yield of crops. With respect to species whose vegetative organs (roots, shoots, leaves) are regarded as commercial yield, higher yield can be obtained through rational increase of nitrogen fertilizer doses and supplementation with other macro- and microelements. Nitrogen is a very important structural element in plants, which contain between 1 and $6 \%$ of nitrogen in dry mass, and nitrogen deficiency significantly inhibits production 
of new plant tissues. An optimum supply of nitrogen ensures proper development of plants. Nitrogen is a constituent of nucleic acids, nucleotides, coenzymes, chlorophyll, phytohormones and cytokinins (GABRYś 2002).

Proper application of fertilizers has a positive effect on plant nutrition, although excessive amounts of nitrogen fertilizers diminish the quality of yield, impair resistance of plants to weather conditions (drought, wind, temperature) or pathogens, depress the consumption value and shorten storage life (Wóscik-WолткоWiak et al. 2000). In order to keep in good health, people need an optimum diet, which must comprise fruit and vegetables of the highest possible biological value (ŚMIECHOwSKA, PRZYBYŁOWSKI 2000).

The aim of this paper has been to investigate the effect of varied nitrogen fertilization on yield and chemical composition of edible parts of leaf beet. In the experiment, three nitrogen doses were applied $(0.2,0.4,0.6 \mathrm{~g}$ $\mathrm{N} \mathrm{dm}{ }^{-3}$ of the growth medium) in the form of ammonium nitrate or urea.

\section{MATERIAL AND METHODS}

The experiment on Beta vulgaris L. cv. Vulcan was conducted in 2009 (20.03-19.05) and 2010 (07.04-31.05). The vegetable was grown for 62 days from sowing to harvesting (37 days from planting to the permanent site).

The experiment was set up in a complete randomization design with 6 series and 8 replications. Single plants were grown in 4-liter pots, filled with highmoor peat limed with $\mathrm{CaCO}_{3}$. The content of mineral compounds in peat prior to planting to the permanent site was (in $\mathrm{mg} \mathrm{dm}^{-3}$ ): $\mathrm{N}-\mathrm{NH}_{4}-\mathrm{tr}$., $\mathrm{N}-\mathrm{NO}_{3}-15, \mathrm{P}^{-} \mathrm{PO}_{4}$-tr., $\mathrm{K}-12, \mathrm{Ca}-58, \mathrm{Mg}-8$.

The following fertilizers were used in the experiment: ammonium nitrate $-34 \% \mathrm{~N}$, urea $-46 \% \mathrm{~N}$, monobasic potassium phosphate $-23 \% \mathrm{P}$, $28.2 \% \mathrm{~K}\left(0.5 \mathrm{P}, 0.6 \mathrm{~K} \mathrm{~g} \mathrm{dm}^{-3}\right)$, magnesium sulphate - $15.6 \% \mathrm{Mg}(0.5 \mathrm{~g}$ $\left.\mathrm{Mg} \mathrm{dm}{ }^{-3}\right)$, microelements.

Three doses of nitrogen: $0.2,0.4,0.6 \mathrm{~g} \mathrm{~N} \mathrm{dm}^{-3}$ in the form of ammonium nitrate or urea were applied in the experiment. Prior to planting to the permanent site, the entire dose of phosphorus, calcium, microelements and L' dose of nitrogen, potassium and magnesium were applied (14.04.2009; 27.04.2010). The remaining amounts of nutrients $(\mathrm{N}, \mathrm{K}, \mathrm{Mg}$ ) were applied on two days during the vegetation period (24.04 and 05.05.2009; 07.05 and 17.05.2010).

Mineral compounds $\mathrm{N}-\mathrm{NH}_{4}, \mathrm{~N}^{-\mathrm{NO}_{3}}, \mathrm{P}_{-} \mathrm{PO}_{4}, \mathrm{~K}, \mathrm{Ca}, \mathrm{Mg}, \mathrm{S}_{-} \mathrm{SO}_{4}, \mathrm{Cl}$ in the medium were determined in an extract of $0.03 \mathrm{M}$ of acetic acid at a volumetric solution to medium ratio of 10:1, with addition of active carbon (NowoSIELSKI 1988). 
Nitrate nitrogen and ammonium nitrogen were analyzed with Bremner method according to Starck modification. Phosphorus was determined with ammonium metavanadate, $\mathrm{S}_{-} \mathrm{SO}_{4}$ - with barium chloride, $\mathrm{Cl}$ - with silver nitrate by colorimetry, and potassium, calcium and magnesium were determined with atomic absorption spectrometry ASA (Perkin-Elmer, Analyst 300). The $\mathrm{pH}$ of the medium was checked as well as the salt concentration (EC) in $\mathrm{mS} \mathrm{cm}^{-1}$ in a suspension of distilled water and the examined medium in a $2: 1$ volumetric ratio (NowOSIELSKI 1988).

Fresh mass yield was determined by measuring the height and weight of aerial parts of the plants on termination of the experiment. L-ascorbic acid was determined with Tillmans method in fresh plant material (PN-A-04019 1998) and the extract was analyzed refractometrically. The dry material was analyzed for total nitrogen with Kjeldahl method and after dry mineralization at $550^{\circ} \mathrm{C}$, after dissolving ash with muriatic acid diluted in water in a $1: 2$ vol. ratio. $\mathrm{P}, \mathrm{K}, \mathrm{Ca}, \mathrm{Mg}$ were determined with the same methods as applied to the medium analysis. $\mathrm{N}-\mathrm{NH}_{4}, \mathrm{~N}-\mathrm{NO}_{3}, \mathrm{~S}_{-} \mathrm{SO}_{4}, \mathrm{Cl}$ were determined in $2 \%$ extract of acetic acid with the same methods as applied to the medium analysis. The microelements $\mathrm{Fe}, \mathrm{Zn}, \mathrm{Mn}$ and $\mathrm{Cu}$ were determined after dry mineralization at $550{ }^{\circ} \mathrm{C}$ with the ASA method.

The results were verified statistically using analysis of variance on mean values and the differences were evaluated with Tukey's test at the significance level $\alpha=0.05$.

\section{RESULTS AND DISCUSSION}

Visually, no differences in plant pigmentation were observed under the influence of the examined factors, and all the plants were characterized by the deep green color of leaves with red ribs of leaf blades and petioles.

The experiment showed significant effect of nitrogen dose and type of nitrogen fertilizer on the yield of leaf beet and length of leaves. The highest yield of leaves (351.8 $\mathrm{g} \mathrm{plant}^{-1}$ ) was obtained after the application of $0.4 \mathrm{~g}$ $\mathrm{N} \mathrm{dm}^{-3}$ in the form of $\mathrm{NH}_{4} \mathrm{NO}_{3}$. The lowest yield $\left(221 \mathrm{~g} \mathrm{plant}^{-1}\right)$ was obtained after the application of lowest nitrogen dose $\left(0.2 \mathrm{~g} \mathrm{dm}^{-3}\right)$ in the form of $\mathrm{CO}\left(\mathrm{NH}_{2}\right)_{2}$. When $\mathrm{NH}_{4} \mathrm{NO}_{3}$ was used for fertilization, plants were higher than from the treatments where $\mathrm{CO}\left(\mathrm{NH}_{2}\right)_{2}$.was applied. Analyzing the effect of a fertilizer dose on the size of plants, it was discovered that plants which had received $0.4 \mathrm{~g} \mathrm{~N} \mathrm{dm}^{-3}$ ) in the form of $\mathrm{NH}_{4} \mathrm{NO}_{3}$ and $\mathrm{CO}\left(\mathrm{NH}_{2}\right)_{2}$ were higher by approx. $3 \mathrm{~cm}$ than the ones from the treatments with the lowest dose of $\mathrm{N}\left(0.2 \mathrm{~g} \mathrm{dm}^{-3}\right)$ - Table 1 .

Many authors who have tested the effect of a nitrogen fertilizer dose on the volume of yield of vegetables confirm the positive effect of increasing nitrogen doses on yield of fresh mass (Dzida 2004, Koџota, Czerniak 2010). 
Table 1

Plant unit weight, leaf length, L-ascorbic acid, dry matter, protein and extract content in beet leaves, depending on nitrogen fertilization

\begin{tabular}{|c|c|c|c|c|c|c|c|}
\hline $\begin{array}{l}\text { Nitrogen } \\
\text { fertilizer }\end{array}$ & $\begin{array}{c}\text { Dose N } \\
\left(\mathrm{g} \mathrm{dm}^{-3}\right)\end{array}$ & $\begin{array}{l}\text { Plant unit } \\
\text { weight } \\
\text { (g) }\end{array}$ & $\begin{array}{c}\text { Leaf } \\
\text { length } \\
(\mathrm{cm})\end{array}$ & $\begin{array}{c}\text { Dry } \\
\text { matter } \\
(\%)\end{array}$ & $\begin{array}{l}\text { L-ascorbic } \\
\text { acid } \\
\text { (mg } 100 \mathrm{~g}^{-1} \\
\text { f.w.) }\end{array}$ & $\begin{array}{l}\text { Protein } \\
(\%)\end{array}$ & $\begin{array}{c}\text { Extract } \\
(\%)\end{array}$ \\
\hline \multirow{3}{*}{$\mathrm{NH}_{4} \mathrm{NO}_{3}$} & 0.2 & 268.8 & 48.25 & 8.91 & 36.60 & 16.75 & 4.87 \\
\hline & 0.4 & 351.8 & 51.50 & 7.83 & 42.50 & 32.21 & 4.10 \\
\hline & 0.6 & 327.7 & 49.50 & 7.50 & 39.70 & 37.29 & 3.73 \\
\hline \multicolumn{2}{|c|}{ Mean for $\mathrm{NH}_{4} \mathrm{NO}_{3}$} & 316.2 & 49.75 & 8.08 & 39.60 & 28.75 & 4.23 \\
\hline \multirow{3}{*}{$\mathrm{CO}\left(\mathrm{NH}_{2}\right)_{2}$} & 0.2 & 221.0 & 42.63 & 8.45 & 39.70 & 33.56 & 5.17 \\
\hline & 0.4 & 239.1 & 45.25 & 7.31 & 40.97 & 33.94 & 4.93 \\
\hline & 0.6 & 224.7 & 41.75 & 8.23 & 32.90 & 37.52 & 5.00 \\
\hline \multicolumn{2}{|c|}{ Mean for $\mathrm{CO}\left(\mathrm{NH}_{2}\right)_{2}$} & 228.3 & 43.21 & 7.99 & 37.86 & 35.01 & 5.03 \\
\hline \multirow{3}{*}{$\begin{array}{l}\text { Mean for } \\
\text { dose }\end{array}$} & 0.2 & 244.9 & 45.44 & 8.68 & 38.15 & 25.16 & 5.02 \\
\hline & 0.4 & 295.5 & 48.38 & 7.57 & 41.74 & 33.08 & 4.52 \\
\hline & 0.6 & 276.2 & 45.63 & 7.86 & 36.30 & 37.41 & 4.37 \\
\hline \multirow{3}{*}{\multicolumn{2}{|c|}{$\begin{array}{l}\mathrm{LSD}_{0.05} \\
\text { Fertilizer N } \\
\text { Dose N } \\
\text { Nitrogen fertilizer x } \\
\text { dose nitrogen }\end{array}$}} & 12.2 & & & & & \\
\hline & & 18.03 & 2.79 & i.d. & i.d. & 4.89 & i.d. \\
\hline & & 31.35 & i.d. & i.d. & i.d. & 8.72 & i.d. \\
\hline
\end{tabular}

i.d. - insignificant differences

Micha£ojć (1994), KoziK (2006) as well as Jarosz and Dzida (2006) obtained higher yields after application of increasing nitrogen fertilization. KALEMBASA and DEsKA (1996), however, reported different results from their research on lettuce, in which they showed that an increase of nitrogen fertilizer doses did not have a distinct effect on lettuce yield.

Our analysis of the plant material showed that as the nitrogen dose introduced to the growth medium increased, the content of nitrates in leaves likewise increased. The content of nitrates in the leaves depended on the type of nitrogen fertilizer and its dose. Less of nitrates was in leaves of plants fertilized with $\mathrm{CO}\left(\mathrm{NH}_{2}\right)_{2}$ than in leaves of plants fertilized with $\mathrm{NH}_{4} \mathrm{NO}_{3}$. The lowest level of nitrates $(0.11 \%$ d.m. $)$ was determined after the application of the lowest dose of $\mathrm{CO}\left(\mathrm{NH}_{2}\right)_{2}$, and the highest one (1\% d.m.) following the application of the highest dose of $\mathrm{NH}_{4} \mathrm{NO}_{3}$. The ammonium form of nitrogen in leaves of Beta vulgaris L. appeared in trace amounts (Table 2).

Increasing doses of nitrogen fertilizers can lead to the growth of nitrates in plant material (MichaLIK, STĘPOWSKA 1995, WoJCIECHOWSKA et al. 2000). KRĘ̇̇EL and КоєОTA (2007), who analyzed the content of nitrates in red beet, confirmed the above conclusion with their experimental results. Vegetables 
Macroelements in beet leave depending on nitrogen fertilizing (\% d.m.)

\begin{tabular}{|c|c|c|c|c|c|c|c|c|c|c|}
\hline $\begin{array}{l}\text { Nitrogen } \\
\text { fertilizer }\end{array}$ & $\begin{array}{c}\text { Dose N } \\
\left(\mathrm{g} \mathrm{dm}^{-3}\right)\end{array}$ & N-total & $\mathrm{N}-\mathrm{NH}_{4}$ & $\mathrm{~N}-\mathrm{NO}_{3}$ & $\mathrm{P}$ & K & $\mathrm{Ca}$ & $\mathrm{Mg}$ & $\mathrm{S}$ & $\mathrm{Cl}$ \\
\hline \multirow{3}{*}{$\mathrm{NH}_{4} \mathrm{NO}_{3}$} & 0.2 & 2.68 & 0.10 & 0.35 & 2.12 & 4.45 & 0.86 & 0.62 & 0.34 & 1.16 \\
\hline & 0.4 & 5.15 & 0.06 & 0.70 & 1.87 & 4.45 & 0.61 & 0.67 & 0.29 & 1.22 \\
\hline & 0.6 & 5.97 & 0.04 & 1.00 & 1.13 & 4.27 & 0.33 & 0.46 & 0.22 & 1.16 \\
\hline \multicolumn{2}{|c|}{ Mean for $\mathrm{NH}_{4} \mathrm{NO}_{3}$} & 4.60 & 0.06 & 0.68 & 1.71 & 4.39 & 0.60 & 0.58 & 0.29 & 1.18 \\
\hline \multirow{3}{*}{$\mathrm{CO}\left(\mathrm{NH}_{2}\right)_{2}$} & 0.2 & 5.37 & 0.04 & 0.11 & 2.20 & 4.84 & 0.59 & 0.48 & 0.41 & 0.44 \\
\hline & 0.4 & 5.43 & 0.08 & 0.19 & 2.24 & 4.61 & 0.40 & 0.39 & 0.43 & 0.42 \\
\hline & 0.6 & 6.43 & 0.16 & 0.23 & 2.28 & 4.67 & 0.35 & 0.42 & 0.46 & 0.53 \\
\hline \multicolumn{2}{|c|}{ Mean for $\mathrm{CO}\left(\mathrm{NH}_{2}\right)_{2}$} & 5.74 & 0.09 & 0.18 & 2.24 & 4.71 & 0.45 & 0.43 & 0.43 & 0.46 \\
\hline \multirow{3}{*}{ Mean for dose } & 0.2 & 4.03 & 0.07 & 0.23 & 2.16 & 4.65 & 0.73 & 0.55 & 0.37 & 0.80 \\
\hline & 0.4 & 5.29 & 0.07 & 0.45 & 2.06 & 4.53 & 0.51 & 0.53 & 0.36 & 0.82 \\
\hline & 0.6 & 6.20 & 0.10 & 0.62 & 1.71 & 4.47 & 0.34 & 0.44 & 0.34 & 0.85 \\
\hline \multicolumn{2}{|l|}{$\mathrm{LSD}_{0.05}$} & & & & & & & & & \\
\hline \multicolumn{2}{|l|}{ Fertilizer N } & 0.320 & 0.019 & 0.026 & 0.116 & 0.221 & 0.07 & 0.04 & 0.033 & 0.063 \\
\hline \multicolumn{2}{|l|}{ Dose N } & 0.479 & 0.029 & 0.039 & 0.175 & i.d. & 0.106 & 0.06 & i.d. & i.d. \\
\hline \multicolumn{2}{|c|}{$\begin{array}{l}\text { Nitrogen fertilizer } \mathrm{x} \\
\text { dose nitrogen }\end{array}$} & 0.854 & 0.052 & 0.071 & 0.311 & i.d. & 0.189 & 0.105 & 0.088 & i.d. \\
\hline
\end{tabular}

i.d. - insignificant differences

with a short vegetation period (e.g. spinach) produce higher yield when more nitrogen fertilizer is applied, but simultaneously they absorb excess nitrates and the biological value of yield is lower. Therefore, fertilizing recommendations should be formulated that would consider the highest biological quality of vegetables and not just the highest yield. With the application of $200 \mathrm{~kg}$ $\mathrm{N}$ per $1 \mathrm{ha}$, the highest yield of spinach was produced, but when using $80 \mathrm{~kg} \mathrm{~N}$ per 1 ha the biological value of yield was much more superior (quality of protein, content of nutrients, vitamin $\mathrm{C}$ and carbohydrates) while the content of nitrates was low.

The content of nitrates in plant material is mostly affected by nitrogen fertilization, but also by the plant species and variety, harvest date, insolation, and the growth medium (KozIK 2006, DzIDA, JAROsZ 2010).

Plant species have different nitrogen demands. CzuBA (1996) states that application of increasing doses of nitrogen fertilizer to a medium with a high organic matter content has a significant effect on increasing nitrogen concentrations in plants. Among several factors which can lower the nitrogen content in plants, noteworthy is the right timing of harvest.

Different parts of plants tend to accumulate different amounts of nitrogen, e.g. highest amounts of nitrates are gathered in leaf vegetables with a short vegetation period and in Brassica vegetables; less of nitrates will be found in root vegetables, followed by vegetable fruits, and the smallest con- 
centrations of these compounds accumulate in generative parts of plants (SADY 2001, WoJcIEchowska, RożEK 2006).

The average content of total nitrogen in beet leaves was $5.17 \% \mathrm{~d} . \mathrm{m}$. The increasing nitrogen doses were observed to have produced an evident effect on the growth of total nitrogen accumulation in plant leaves. The highest content of $\mathrm{N}$-total $(6.43 \% \mathrm{~d} . \mathrm{m}$.) has been noted in aerial parts of beet cultivated with the highest dose of $\mathrm{CO}\left(\mathrm{NH}_{2}\right)_{2}$, whereas the lowest content of $\mathrm{N}$-total $(2.68 \%$ d.m.) has occurred in leaves of beet supplemented with the lowest dose of $\mathrm{NH}_{4} \mathrm{NO}_{3}$ (Table 2).

Interesting results were obtained from our analysis of the content L-ascorbic acid in Beta vulgaris L. The applied doses of nitrogen fertilizer differentiated the vitamin $\mathrm{C}$ concentration in the examined plants, but the effect was ambiguous. Plants fertilized with the average nitrogen dose of $0.4 \mathrm{~g} \mathrm{dm}^{-3}$ in the form of $\mathrm{NH}_{4} \mathrm{NO}_{3}$ were characterized by the highest content of vitamin $\mathrm{C}\left(42.5 \mathrm{mg} 100 \mathrm{~g}^{-1}\right.$ f.m.), whereas the lowest content of vitamin $\mathrm{C}$ (32.9 mg $100 \mathrm{~g}^{-1}$ f.m.) was obtained in response to the fertilization with $0.6 \mathrm{~g} \mathrm{~N} \mathrm{dm}^{-3}$ as $\mathrm{CO}\left(\mathrm{NH}_{2}\right)_{2}$. While analyzing the effect of nitrogen fertilizer type on vitamin $\mathrm{C}$ in leaf beet, higher vit. $\mathrm{C}$ concentration was found in plants fertilized with $\mathrm{NH}_{4} \mathrm{NO}_{3}$ than in plants supplemented with $\mathrm{CO}\left(\mathrm{NH}_{2}\right)_{2}$ - Table 1 . The results of our study show that increasing doses of nitrogen in the form of $\mathrm{CO}\left(\mathrm{NH}_{2}\right)_{2}$ depress the L-ascorbic acid content in leaf beet plant. A similar dependence was demonstrated by KozIK (1998) in experiments conducted on lettuce. However, DzIDA and PITURA (2008) as well as VENTER (1983) in their experiments with leaf beet noted a higher vitamin C content in response to a growing nitrogen dose. In addition, PoKLuDA and KubeN (2002) claim that the vitamin C content in leaf beet plants also depends on its variety. The varieties Beta vulgaris which they analyzed were characterized by a wide range of vitamin $\mathrm{C}$ concentration, between 23.8 and $37.8 \mathrm{mg} 100 \mathrm{~g}^{-1}$ f.m.

The average content of protein in beet leaves was $31.88 \% \mathrm{~d} . \mathrm{m}$. The increasing nitrogen doses clearly raised the protein accumulation in leaves has been noted. Raising the nitrogen dose from 0.2 to $0.4 \mathrm{~g} \mathrm{dm}^{-3}$ in the growth medium led to a decrease in the dry matter and extract content in beet leaves, regardless of the applied nitrogen fertilizer (Table 1).

Significant influence of the nitrogen fertilizer type on all the determined nutrients present in aerial parts of leaf beet was noted. Leaves of plants fertilized with urea accumulated more $\mathrm{N}$-total, N-NH $\mathrm{NH}_{4}, \mathrm{P}, \mathrm{K}, \mathrm{S}, \mathrm{Fe}, \mathrm{Zn}, \mathrm{Mn}$ and $\mathrm{Cu}$ compared to plants which were fertilized with ammonium nitrate. Also the dose of used nitrogen fertilizers had a significant effect on the mineral composition of leaf beet. When the nitrogen dose rose from 0.2 to $0.4 \mathrm{~g} \mathrm{dm}^{-3}$ in the medium, the $\mathrm{Fe}$ and $\mathrm{Cu}$ content in beet leaves increased, while the concentrations of $\mathrm{K}, \mathrm{Ca}, \mathrm{Zn}$ and $\mathrm{Mn}$ declines, irrespective of the applied nitrogen fertilizer (Tables 2 and 3 ). 
Table 3

Microelements in beet leave on nitrogen fertilizing (\% d.m.)

\begin{tabular}{|c|c|c|c|c|c|}
\hline Nitrogen fertilizer & $\begin{array}{c}\text { Dose N } \\
\left(\mathrm{g} \mathrm{dm}^{-3}\right)\end{array}$ & $\mathrm{Fe}$ & $\mathrm{Zn}$ & $\mathrm{Mn}$ & $\mathrm{Cu}$ \\
\hline $\mathrm{NH}_{4} \mathrm{NO}_{3}$ & $\begin{array}{l}0.2 \\
0.4 \\
0.6\end{array}$ & $\begin{array}{l}82.54 \\
97.47 \\
89.73\end{array}$ & $\begin{array}{l}112.0 \\
94.5 \\
70.5\end{array}$ & $\begin{array}{l}483.0 \\
469.5 \\
461.0\end{array}$ & $\begin{array}{c}9.24 \\
10.28 \\
7.87\end{array}$ \\
\hline \multicolumn{2}{|l|}{ Mean for $\mathrm{NH}_{4} \mathrm{NO}_{3}$} & 89.91 & 92.33 & 471.1 & 9.13 \\
\hline $\mathrm{CO}\left(\mathrm{NH}_{2}\right)_{2}$ & $\begin{array}{l}0.2 \\
0.4 \\
0.6\end{array}$ & $\begin{array}{l}128.7 \\
141.0 \\
144.8 \\
\end{array}$ & $\begin{array}{l}179.0 \\
130.5 \\
107.5\end{array}$ & $\begin{array}{l}635.0 \\
441.0 \\
488.0\end{array}$ & $\begin{array}{c}12.81 \\
13.24 \\
5.24 \\
\end{array}$ \\
\hline \multicolumn{2}{|l|}{ Mean for $\mathrm{CO}\left(\mathrm{NH}_{2}\right)_{2}$} & 138.2 & 139.0 & 521.3 & 10.43 \\
\hline Mean for dose & $\begin{array}{l}0.2 \\
0.4 \\
0.6\end{array}$ & $\begin{array}{l}105.6 \\
119.2 \\
117.2\end{array}$ & $\begin{array}{l}145.5 \\
112.5 \\
89.0\end{array}$ & $\begin{array}{l}559.0 \\
455.2 \\
474.5\end{array}$ & $\begin{array}{c}11.03 \\
11.76 \\
6.56\end{array}$ \\
\hline \multicolumn{2}{|c|}{$\begin{array}{l}\mathrm{LSD}_{0.05} \\
\text { Fertilizer } \mathrm{N} \\
\text { Dose } \mathrm{N} \\
\text { Nitrogen fertilizer } \mathrm{x} \text { dose nitrogen }\end{array}$} & $\begin{array}{l}3.758 \\
5.773 \\
10.59\end{array}$ & $\begin{array}{l}6.422 \\
9.865 \\
18.09\end{array}$ & $\begin{array}{l}2.854 \\
4.385 \\
8.045\end{array}$ & $\begin{array}{l}0.488 \\
0.749 \\
1.374\end{array}$ \\
\hline
\end{tabular}

i.d. - insignificant differences

The results of the chemical analysis of the growth media are contained in Table 4 . The mineral nitrogen content $\left(\mathrm{N}_{-} \mathrm{NH}_{4}+\mathrm{N}-\mathrm{NO}_{3}\right)$ depended on the size of a dose of nitrogen fertilizers, and tended to increase at higher rates of nitrogen fertilizers. The highest concentration of ammonium nitrogen was noted in the medium enriched with the highest dose of nitrogen $\left(0.6 \mathrm{~g} \mathrm{dm}^{-3}\right)$ in the form of $\mathrm{CO}\left(\mathrm{NH}_{2}\right)_{2}$.

In the treatments with urea, the concentration of potassium was $68 \%$ higher than in the treatments fertilized with ammonium nitrate, which resulted in a higher concentration of salt in the medium when urea was used for fertilization.

The reaction of the growth media remained within the range of 5.58 and 6.15. The level of nitrogen fertilization ambiguously differentiated $\mathrm{pH}$ of the medium in treatments with $\mathrm{NH}_{4} \mathrm{NO}_{3}$, but when a double dose of nitrogen in the form of $\mathrm{CO}\left(\mathrm{NH}_{2}\right)_{2}$ had been used, a rise in the medium $\mathrm{pH}$ was noticed.

When the dose of $0.6 \mathrm{~g} \mathrm{~N} \mathrm{dm}^{-3}$ in the form of $\mathrm{CO}\left(\mathrm{NH}_{2}\right)_{2}$ had been used for plant nutrition, the medium was characterized by the highest EC value $\left(1.41 \mathrm{mS} \mathrm{cm}{ }^{-1}\right)$. The total concentration of salt in the medium was in the range of 0.65 and $1.41 \mathrm{mS} \mathrm{cm}-1$. Increasing doses of nitrogen fertilization, whether as $\mathrm{NH}_{4} \mathrm{NO}_{3}$ or $\mathrm{CO}\left(\mathrm{NH}_{2}\right)_{2}$, were followed by increasing salt concentrations in the growth medium. 


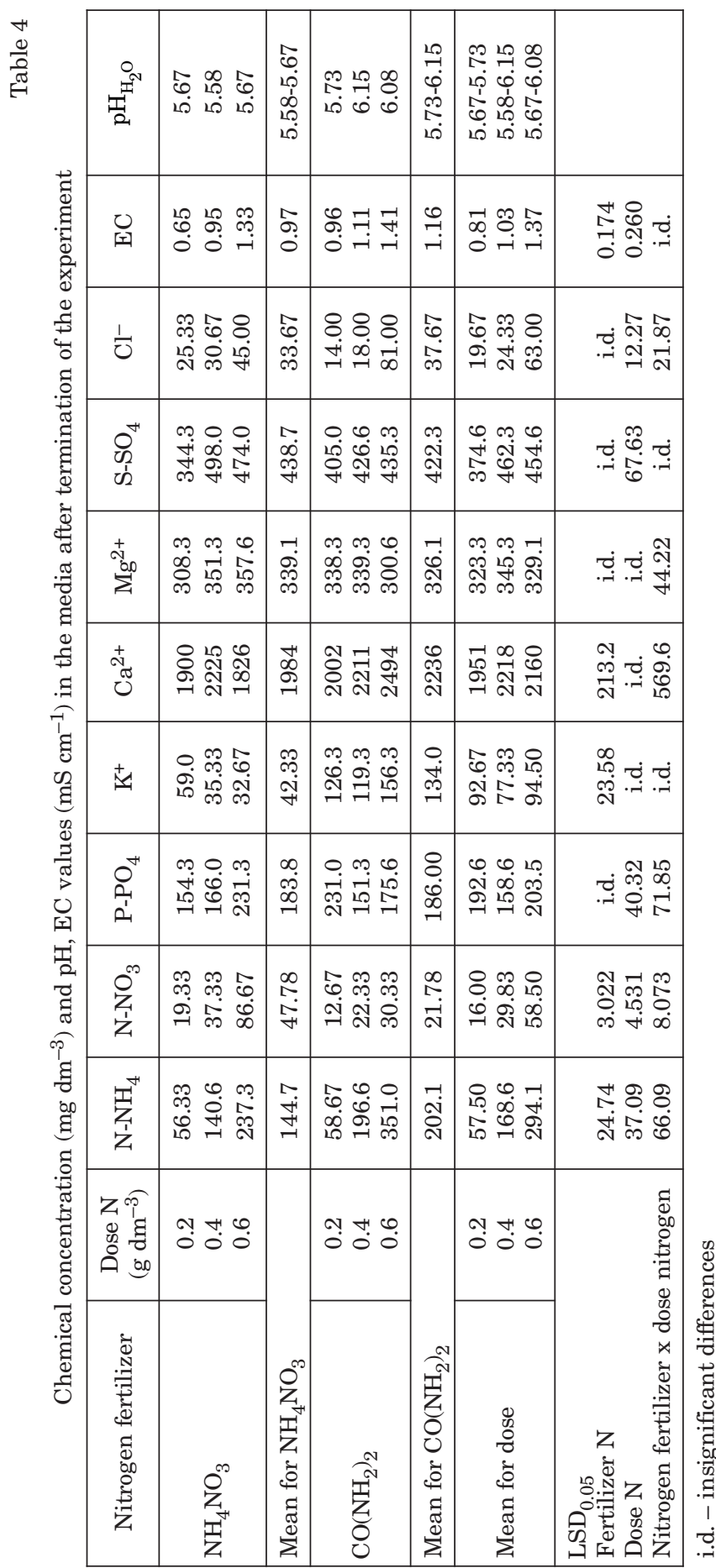




\section{CONCLUSIONS}

1. In cultivation of leaf beet, an application of $0.4 \mathrm{~g} \mathrm{~N} \mathrm{dm}^{-3} \mathrm{NH}_{4} \mathrm{NO}_{3}$ proved to be the most favourable, as it led to the highest yield of fresh mass of leaves and the highest L-ascorbic acid content. In turn, owing to the lowest share of nitrates in the dry mass of leaves, an application of $0.2 \mathrm{~g} \mathrm{~N} \mathrm{dm}^{-3}$ of the medium in the form of urea proved to be most superior.

2. When urea had been used for leaf beet fertilization, the aerial parts of this plant accumulated more N-total, $\mathrm{N}^{-N_{4}}, \mathrm{P}, \mathrm{K}, \mathrm{S}, \mathrm{Fe}, \mathrm{Zn}, \mathrm{Mn}, \mathrm{Cu}$ than in plants nourished with ammonium nitrate.

3. Regardless of the type of nitrogen fertilizer, an increase of the total salt concentration (EC) in the growth medium occurred in response to the growing doses of nitrogen fertilizers.

\section{REFERENCES}

Biesiada A., Коџота E. 2010. The effect of nitrogen fertilization on yielding and chemical composition of radicchio chicory for autumn - harvest cultivation. Acta Sci. Pol. Hort. Cult., 9(4): 85-91.

Czuba R. 1996. Technika nawożenia mineralnego a zawartość azotanów $w$ roślinach [Mineral fertilization technology versus the content of nitrates in plants]. Zesz. Probl. Post. Nauk Rol., 440: 65-73. (in Polish)

Dzida K. 2004. Wptyw nawożenia azotowo-potasowego na plonowanie buraka liściowego (Beta vulgaris L. var. cicla L.) i zawartość sktadników $w$ podtożu [Effect of nitrogenpotassium fertilization on yields of leaf beet (Beta vulgaris L. var. cicla L.) and concentration of nutrients in the growth medium]. Rocz. AR Pozn., CCCVI, Ogrodn., 37: 55-60. (in Polish)

DzIDA K., JaRosz J. 2010. Effect of calcium carbonate and differentiated nitrogen fertilization upon the yield and chemical composition of spinach beet. Acta Sci. Pol. Hort. Cul., 9(3): 201-210.

Dzida K., Pitura K. 2008. The influence of varied nitrogen fertilization on yield and chemical composition of swiss chard (Beta vulgaris L. var cicla L.). Acta Sci. Pol. Hort. Cult., 7(3): $15-24$.

Gabryś H. 2002. Gospodarka azotowa. W: Fizjologia roślin. [Nitrogen management. In: Plant physiology]. J. Kopcewicz, S. Lewak. PWN, Warszawa. (in Polish)

JARosz Z., Dzida K. 2006. Wptyw zróżnicowanego nawożenia azotowo-potasowego na plonowanie $i$ sktad chemiczny sataty [Effect of different nitrogen-potassium fertilization regimes on yield and chemical composition of lettuce]. Acta Agroph., 7(3): 591-597. (in Polish)

Kalembasa S., Deska J. 1996. Effect of doses and forms of nitrogen on yield of leaves and nitrate concentration in lettuce. Zesz. Probl. Post. Nauk Rol., 440: 145-149.

Коєота E., Czerniak K. 2010. The effects of nitrogen fertilization on yield and nutritional value of swiss chard. Acta Sci. Pol. Hort. Cult., 9(2): 31-37.

Kozıк E. 1998. Wptyw poziomu nawożenia azotem na plon oraz zawartości cukrów i kwasu askorbinowego $w$ siedmiu odmianach sataty [Effect of nitrogen fertilization level on yield and content of carbohydrates and L-ascorbic acid in seven lettuce varities]. VII Konf. Nauk. nt. Efektywność stosowania nawozów w uprawach ogrodniczych, ss. 93-96. (in Polish) 
Kozıк E. 2006. Wptyw terminu zbioru oraz nawożenia azotem i potasem na zawartość azotanów $w$ satacie uprawianej $w$ szklarni [Effect of harvest date and nitrogen-potassium fertilization on the content of nitrates in lettuce grown in the greenhouse]. Acta Agroph., 7: 633-642. (in Polish)

Kretschmer M., 1999. Rote Rübe Und Mangold (Beta vulgaris L.). Gemüse, 8:507.

KRĘ̇̇eL J., KоєотA E. 2007. Wptyw nawożenia azotowego na plonowanie i wartość biologiczna buraka ćwiktowego uprawianego na zbiór pęczkowy [Role of nitrogen fertilization on yield and biological value of the beetroot grown for bunch harvest]. Rocz. AR Pozn. CCCLXXXIII, Ogrodn., 41: 547-552. (in Polish)

Michalik H., StęPowska A. 1995. Zawartość azotanów w kilku odmianach sataty mastowej uprawianej pod ostonami. Żywność Technologia Jakość, Kraków, 2(3): 115.

MichaŁoJć Z. 1994. Wptyw zróżnicowanego nawożenia azotowo-potasowego na plonowanie $i$ sktad chemiczny sataty, rzodkiewki, szpinaku. Mat. Konf. nt. Znaczenie potasu i magnezu w uprawie roślin ogrodniczych. Skierniewice, 35-38.

NowosIELSKI O. 1988. Zasady opracowywania zaleceń nawozowych $w$ ogrodnictwie [Principles of preparation of fertilizing recommendations in horticulture]. PWRiL, Warszawa. (in Polish)

PN-A-0419: 1998. Produkty spożywcze - Oznaczanie zawartości witaminy C [Food products - determination of vitamin C content; Polish norms].

Pokluda R., Kuben J. 2002. Comparison of selected Swiss chard (Beta vulgaris ssp. cicla L.) varietes. Hort. Sci., 29(3): 14-118.

SADY W. 2001. Czynniki ograniczające zawartość azotanów i metali ciężkich w warzywach Factors limiting the content of nitrates and heavy metals in vegetables]. Przem. Ferm., 5: 21-23.

Śmiechowska M., PrzybyŁowski P. 2000. Zawartość azotanów (V) oraz azotanów (III) we wspótczesnych warzywach $z$ uprawy ekologicznej [Content of nitrates(V) and nitrates(III) in contemporary organic vegetables]. Rocz. AR Pozn., Ogrod., Cz. I, 31: 521-525. (in Polish)

Venter F. 1983. Der Nitratgehalt In Chinnakohl (Brassica pecinenssi (Lour) Rupr.). Gantenbauwiss, 48: 6-12.

Wojciechowska R., Smoleń S., PrzybyŁo J. 2000. Zawartość azotanów i azotynów w różnych częściach użytkowych wybranych gatunków warzyw [Content of nitrates and nitrites in different edible parts of some vegetable species]. Zesz. Nauk. AR w Krakowie, 364: 221-225. (in Polish)

Wojciechowska R., RożeK S. 2006. Redukcja azotanów w różnych częściach użytkowych warzyw [Reduction of nitrates in different parts of cultivated vegetables]. Fol. Hort., 2: 203-205. (in Polish)

Wójcik-Wojtкowiak D., Politycka B., Mielcarz B. 2000. Wartość biologiczna warzyw nawożonych ziemiq kompostowg [Biological value of vegetables fertilized with compost soil]. Zesz. Nauk. AR Kraków, 71(364): 209-212. (in Polish) 